\title{
Spatio-Temporal Variability of Land use/Land Cover within Koyna River Basin
}

\author{
Tarate Suryakant Bajirao*, Pravendra Kumar and Anil Kumar \\ Department of Soil and Water Conservation Engineering, G. B. Pant University of Agriculture \\ and Technology, Pantnagar - 263145, Uttarakhand, India \\ *Corresponding author
}

\section{A B S T R A C T}

Rapid increase in activities like urbanization, socioeconomic activities and environmental changes are responsible for land use/land cover changes (LULCC). Hence, it is important

\begin{tabular}{|c|}
\hline Keywords \\
\hline $\begin{array}{l}\text { LULCC, Koyna river } \\
\text { basin, Soil } \\
\text { degradation, Accuracy } \\
\text { assessment, NDVI }\end{array}$ \\
\hline Article Info \\
\hline $\begin{array}{l}\text { Accepted: } \\
\text { 08 August } 2018 \\
\text { Available Online: } \\
\text { 10 September } 2018\end{array}$ \\
\hline
\end{tabular}
to know LULCC to determine its impacts on hydrology. In this study an attempt has been made to analyze LULCC in the Koyna river basin, Maharashtra which is an important tributary of the Krishna River. The study reveals that the deep water body slightly increased from $4.52 \%$ in 1999 to $4.75 \%$ in 2015 . The rocky land/ hard surface area increased from $3.06 \%$ in 1999 to $9.57 \%$ in 2015. On the other hand, Agricultural land has decreased from $40.25 \%$ in 1999 to $33.68 \%$ in 2015 . Similarly, hilly land has decreased from $37.26 \%$ in 1999 to $32.27 \%$ in 2015 . It is worth observed that from year 1999 to 2015 , the most of the agricultural land has reduced in to hard surface and scrub land. The results also indicated that the thick forest has transformed in to Scrub or open forest from 1999 to 2015. There is a negative change of vegetation coverage or vegetation health for the river basin during 1999-2015, as the most of high vegetation coverage (HVC) has disappeared with a great increase of low vegetation coverage (LVC) and medium vegetation coverage (MVC). It is observed that natural and anthropogenic activities have caused significant change in land use/land cover in the study area.

\section{Introduction}

The land use/land cover dynamics are responsible to change the hydrologic performance of catchments (Kidane and Bogale, 2017). The natural and socioeconomic factors are responsible for use of land by man with respect to time and space. Due to increased demographic pressure, the land is becoming very scarce resource. Hence, information on temporal and spatial change of land use/land cover and their optimal use is essential for the selection, planning and implementation of land use schemes to meet the increasing demands for basic human needs and welfare. The land use/land cover change due to increased population and climate change also helps to monitor the trend over long period of time. The study of intensity of land use and its change provides new tool to assess the environmental conditions (Guangming et al., 2010). The purpose for which the land cover is used called land use (Md et al., 2008). The detection of land use/land cover change is essential for decision making and future planning of environmental 
management and natural resource conservation (Zahra, 2016). Land use and land cover change has become a central component in current strategies for managing natural resources and monitoring environmental changes. The increased research in vegetation mapping by using advanced technologies helps to estimate the areal coverage and health of the world's forest, grassland and agricultural resources. Due to different anthropogenic activities over the past few decades, the land use/land cover is changed drastically. This spatial and temporal change results in to disturbed hydrological cycle and natural ecological balance. Hence, in order to stabilize the natural environment the monitoring of land use/land cover is essential. To monitor the deforestation, coastal dynamics, shoreline change and river transportation spatial and temporal change detection is essential (Sandeep et al., 2015). Global warming is the problem caused due to deforestation and loss of biodiversity, (Dewi, 2009).

The establishments of new settlement have contributed to forest degradation and depletion (Bekele, 2001; Nair and Tieguhing, 2004). Identifying land use/land cover effects on hydrological cycle is a current challenge in study of hydrological science (Niem et al., 2010). The response of surface runoff and soil erosion in the hydrological cycle to the precipitation mainly affects due to presence of vegetative cover and its density, hence monitoring of land use and land cover receives greater importance (Jian et al., 2012). Land degradation due to agricultural development, tourism development and industrial growth causes enormous cost to the ecological balance and environment (Ashraf and Yasushi, 2009). The study of different vegetation health indices like Normalized Difference Vegetation Index (NDVI) helps to detect global environmental change (Jian et al., 2012).
Remote Sensing (RS) and Geographic Information System (GIS) are now providing new tools for advanced ecosystem management. Acquiring timely remote sensing data and application of GIS technology are very useful to observe and analyze the periodical changes of land forms and land cover. Remote sensing provides valuable multispectral data for the study areas as per spatial and temporal need (Jie et al., 2011). Integration of remote sensing technique with GIS can enhance the accuracy of environmental impact assessment with respect to time and space (Sumedha et al., 2010). The collection of remotely sensed data facilitates the synoptic analyses of Earth - system function, patterning and change at local, regional and global scales over time; such data also provide an important link between intensive, localized ecological research and regional, national and international conservation. Hence an attempt has been made to analyze land use/land cover changes over Koyna river basin, Maharashtra.

\section{Materials and Methods}

\section{Study area}

The Koyna River is a tributary of the Krishna River which originates in Mahableshwar, Satara district, Western Maharashtra, India. It originates near Mahabaleshwar, a famous hill station in the Western Ghats of Maharashtra state. The Konya River Basin generally trends North - South and covers an area of $1915 \mathrm{~km}^{2}$. The study area lies between $17^{\circ} 7^{\prime} 55^{\prime}, \mathrm{N}$ to $17^{\circ} 57^{\prime} 50.57^{\prime}, \quad \mathrm{N}$ latitude and $73^{\circ} 33^{\prime} 15^{\prime}$ ' E to $74^{\circ} 11^{\prime} 10^{\prime}$ ' E longitude.

\section{Methodology}

Multi temporal satellite data of Landsat 7 and Landsat 8 were used for the analysis. Landsat 7 is the seventh satellite of the Landsat program launched on April 15, 1999 and 
Landsat 8 satellite launched on February 11, 2013. Landsat images collected by Landsat 7, Enhanced Thematic Mapper (ETM+ with path/ row 147/48) on November 14, 1999 and Landsat 8, (OLI/TIRS satellite image with path /row 147/48) on November 18, 1999 were used to classify the study area. The Landsat-7 and 8 sensors have a spatial resolution of $30 \mathrm{~m}$.

Land use/land cover classification was made using ENVI 4.7 digital image processing software. Isodata unsupervised method of classification was used for LULC classification. The ASTER Digital Elevation Model was used. The QGIS software with grass tool was used for delineation of watershed. The land use/land cover classes include Agricultural land, Forest land, Hilly land, Rocky / Hard surface land, Scrub land/open forest land, Deep and shallow water body.

The land use/land cover changes in the Koyna river basin were analyzed for a period of 16 years i.e. from the year 1999 to 2015. Accuracy assessment is necessary for the classification made using remotely sensed data. Error matrix represents the accuracy of classification with producer's accuracy, consumer's accuracy, overall accuracy and kappa coefficient as the different components of accuracy assessment. In this study, the accuracy assessment is carried out by using ENVI 4.7. The Normalized Difference Vegetation Index (NDVI) was also determined by using ENVI 4.7.

\section{Percent change detection}

To compute the LULC change in percentage (\%), final and initial LULC areal coverage was compared using the following formula:

Change percentage $(\%)=\frac{\text { Present LULC area-Previous LULC area }}{\text { Previous LULC area }} \times 100$
Remote sensing monitoring of vegetation coverage

Normalized Difference Vegetation Index (NDVI) is the index of plant greenness and it is used as geographical indicator to assess the health of vegetation. Theoretical range of NDVI is from -1 to 1 . Negative value indicates the presence of water, cloud, rocks etc. Positive value indicates the vegetation health and density.

As the NDVI increases biomass and health also increases. NDVI is calculated on the basis of reflectance of Red and Near Infra-Red (NIR) band. NDVI is the difference of spectral reflectance of NIR and Red band normalized by the summation of these two bands. For the year 2015, Band 5 (NIR) and Band 4 (R) of Landsat 8 were used. Band 4 (NIR) and Band 3 (R) of Landsat 7 were used for the year 1999.

$\mathrm{NDVI}=\frac{\mathrm{NIR}-\mathrm{R}}{\mathrm{NIR}+\mathrm{R}}$

Where,

NIR is Near Infra-Red and R is Red band.

\section{Results and Discussion}

For planning of watershed management, the impact of climate change and land use/land cover change (LULCC) detection on hydrology is essential step. The land use/land cover maps of the study area for two different time periods were analyzed.

The True Color Composite (TCC) and False Color Composite (FCC) of Koyna river basin for the year 1999 and 2015 is shown in Figure $1 \mathrm{a}, 1 \mathrm{~b}, 2 \mathrm{a}$ and $2 \mathrm{~b}$, respectively.

The LULC for the year 1999 and 2015 is given in Figure $3 a$ and $3 b$, respectively. 
The total area covered by each land use/land cover category is also shown in Table 1. It is worth observed that from year 1999 to 2015, most of the agricultural land has reduced in to hard surface and scrub land. The results also indicate that the thick forest has transformed in to Scrub or open forest.

The study reveals that the deep water body slightly increased from $4.52 \%$ in 1999 to $4.75 \%$ in 2015 . The rocky land/ hard surface area increased from $3.06 \%$ in 1999 to $9.57 \%$ in 2015. The results also indicated that the thick forest has transformed in to Scrub or open forest from 1999 to 2015.

On the other hand, agricultural land has decreased from $40.25 \%$ in 1999 to $33.68 \%$ in 2015. Similarly, hilly land has decreased from $37.26 \%$ in 1999 to $32.27 \%$ in 2015 . It is worth observed that from year 1999 to 2015 most of the agricultural land has reduced in to hard surface and scrub land.

\section{Areal extent and change of LULC}

The results on various landforms cover extents and their changes are presented in Tables 1 through 3 . The high altitude areas are mainly covered by forest and the low lying areas by agricultural land. The agricultural land comprises nearly $34 \%$ of the study area and forms an important land cover class which comprises of plantation, crop land and fallow land.

Forest and agriculture land constitute the major part of the study area. Maximum increase in the rocky/hard surface area and consequently the maximum decrease in forest cover are observed during 1999-2015. With the advent of increasing natural and anthropogenic activities, there is maximum increase in the rocky/hard surface area during 1999-2015. It is observed that due to soil erosion and other anthropogenic activities top soil layer has been removed and converted in to hard surface area. Hence, it is observed that natural and anthropogenic activities have caused significant change in land use/ land cover.

\section{LULC classification accuracy}

The producers accuracy and Consumers accuracy of different classes for the year Nov. 1999 and Nov. 2015 are presented in error matrix Tables 4 and 5, respectively. The producers accuracy and Consumers accuracy of different classes for the year Nov. 1999 and Nov. 2015 is found to be very high. The overall accuracy and Kappa coefficient for the Nov. 1999 are $97.93 \%$ and 0.9739, respectively which shows better classification performance.

The overall accuracy and Kappa coefficient for the Nov. 2015 are $99.02 \%$ and 0.9860, respectively which shows extremely high classification performance. The accuracy of classification is observed to be better than expectation.

\section{Vegetation coverage change}

As the land use/land cover changes the vegetation density and hence, the NDVI changes spatially and temporally. In this study the natural vegetation condition is divided into four grades which are full vegetation coverage (FVC, $1 \geq$ NDVI $\geq 0.9$ ), high vegetation coverage (HVC, $0.9>\mathrm{NDVI} \geq 0.5$ ), medium vegetation coverage (MVC, $0.5>\mathrm{NDVI} \geq$ 0.26 ), and low vegetation coverage (LVC, $0.26>\mathrm{NDVI} \geq-1$ ).

As shown in Figure $4 a$ and $4 b$, the vegetation health or density is decreased from the year 1999 to the year 2015. The Table 6 presents the change in the spatial distribution of different vegetation grade during the year 1999 to 2015. 
Int.J.Curr.Microbiol.App.Sci (2018) 7(9): $944-953$

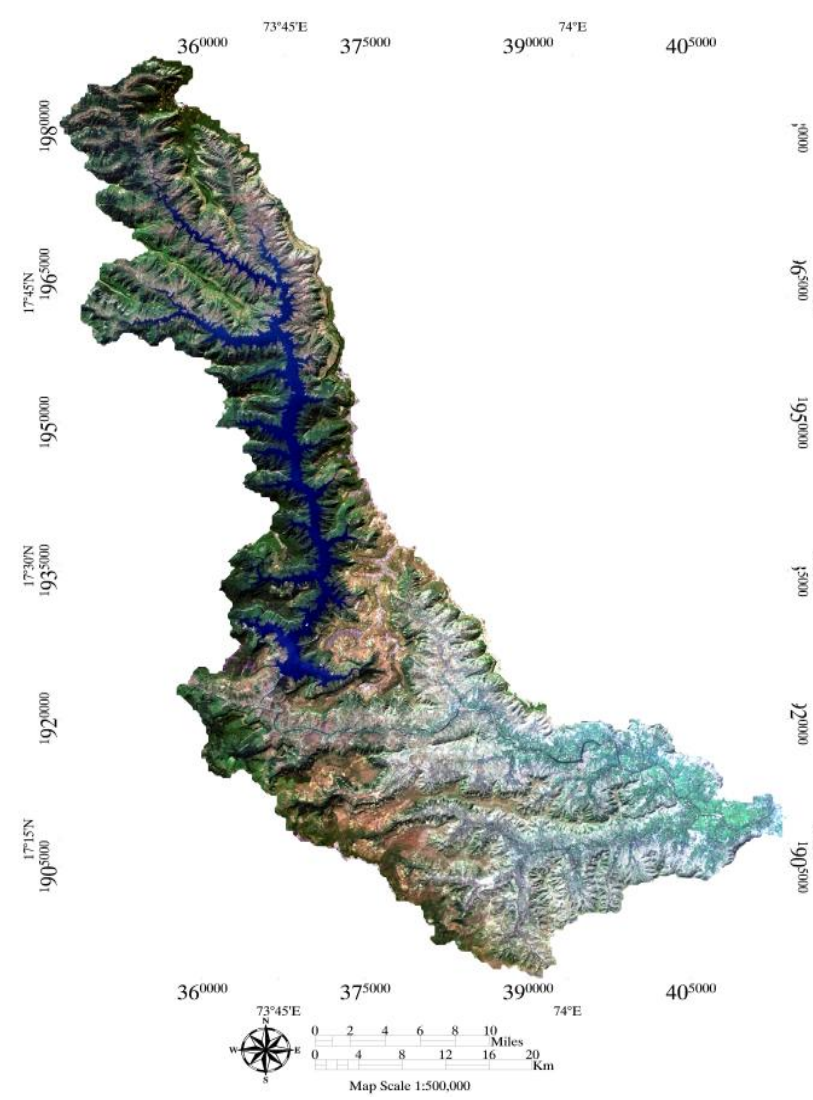

Fig.1a TCC for the year 1999

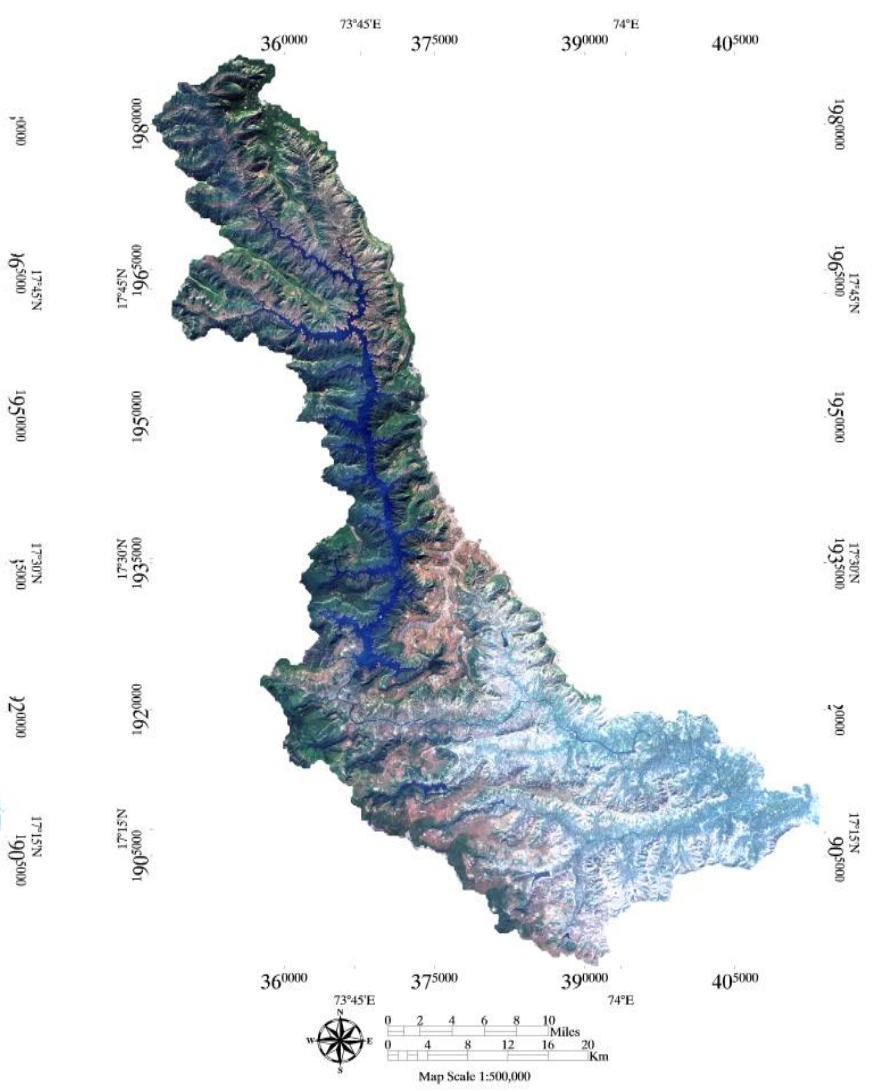

Fig.1b TCC for the year 2015

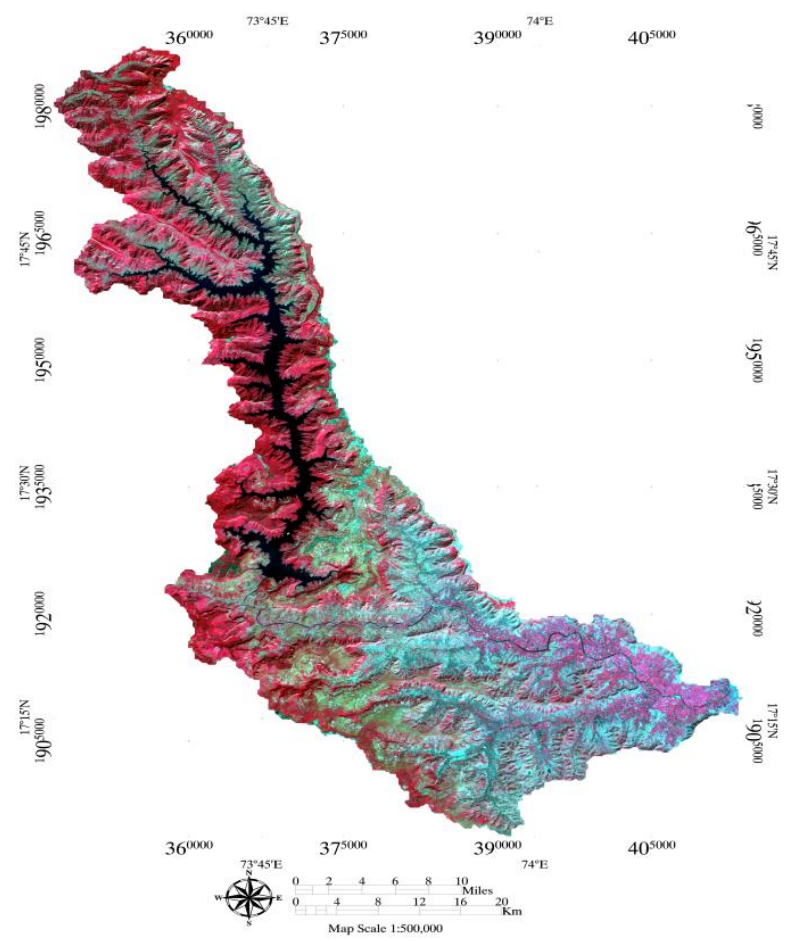

Fig.2a FCC for the year 1999

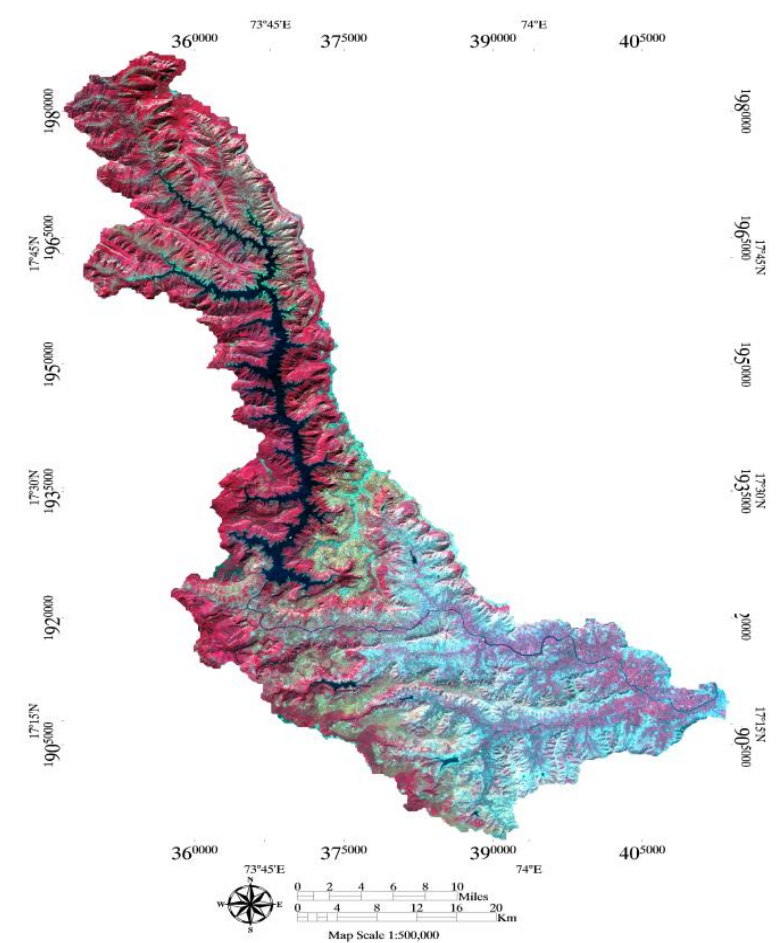

Fig.2b FCC for the year 2015 


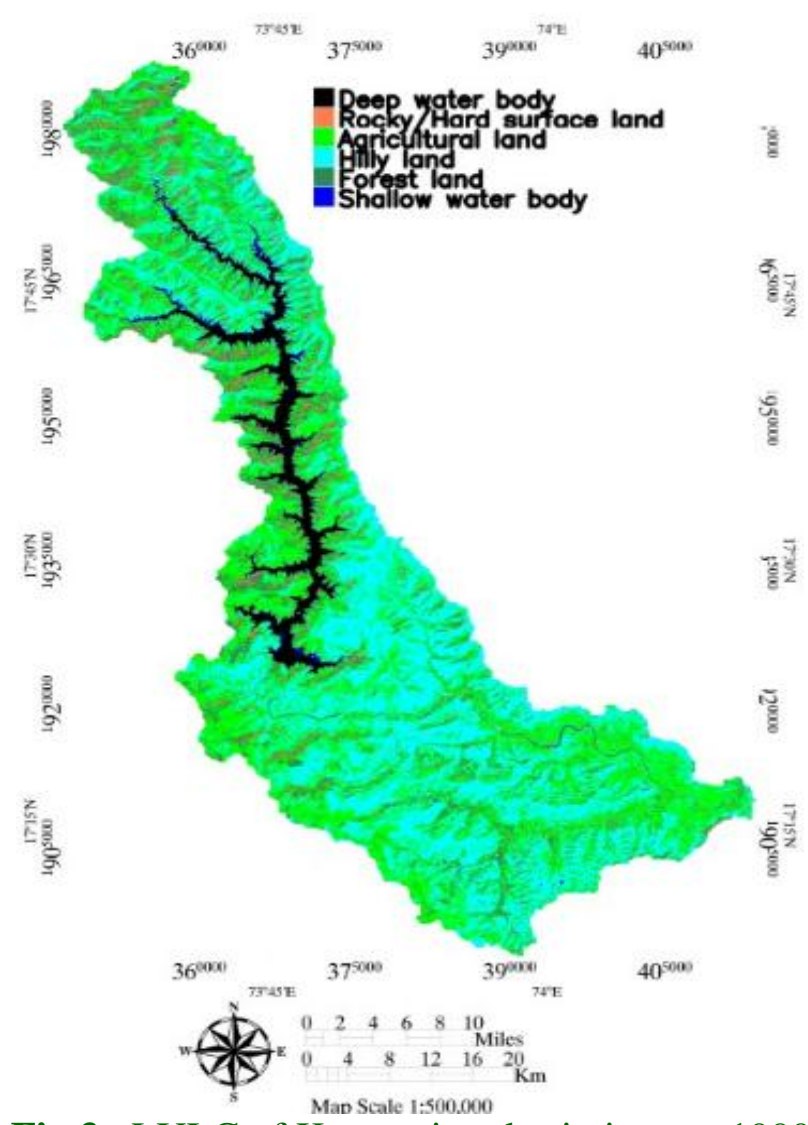

Fig.3a LULC of Koyna river basin in year 1999

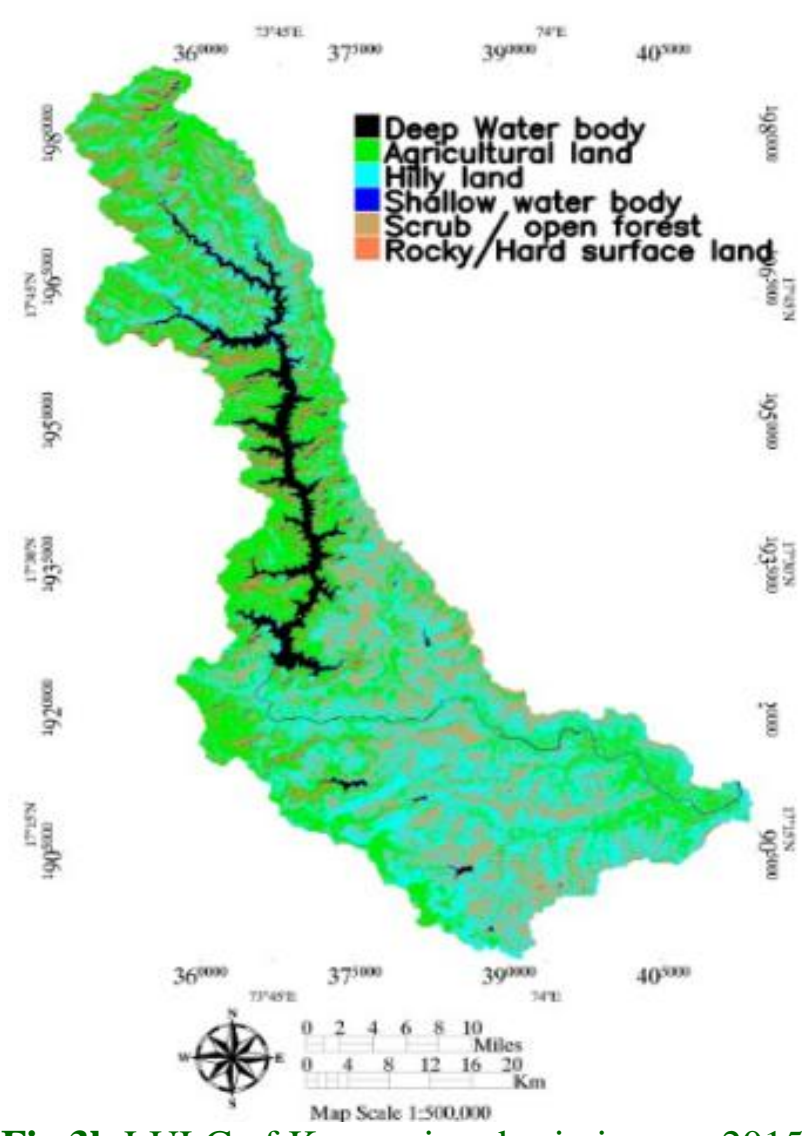

Fig.3b LULC of Koyna river basin in year 2015
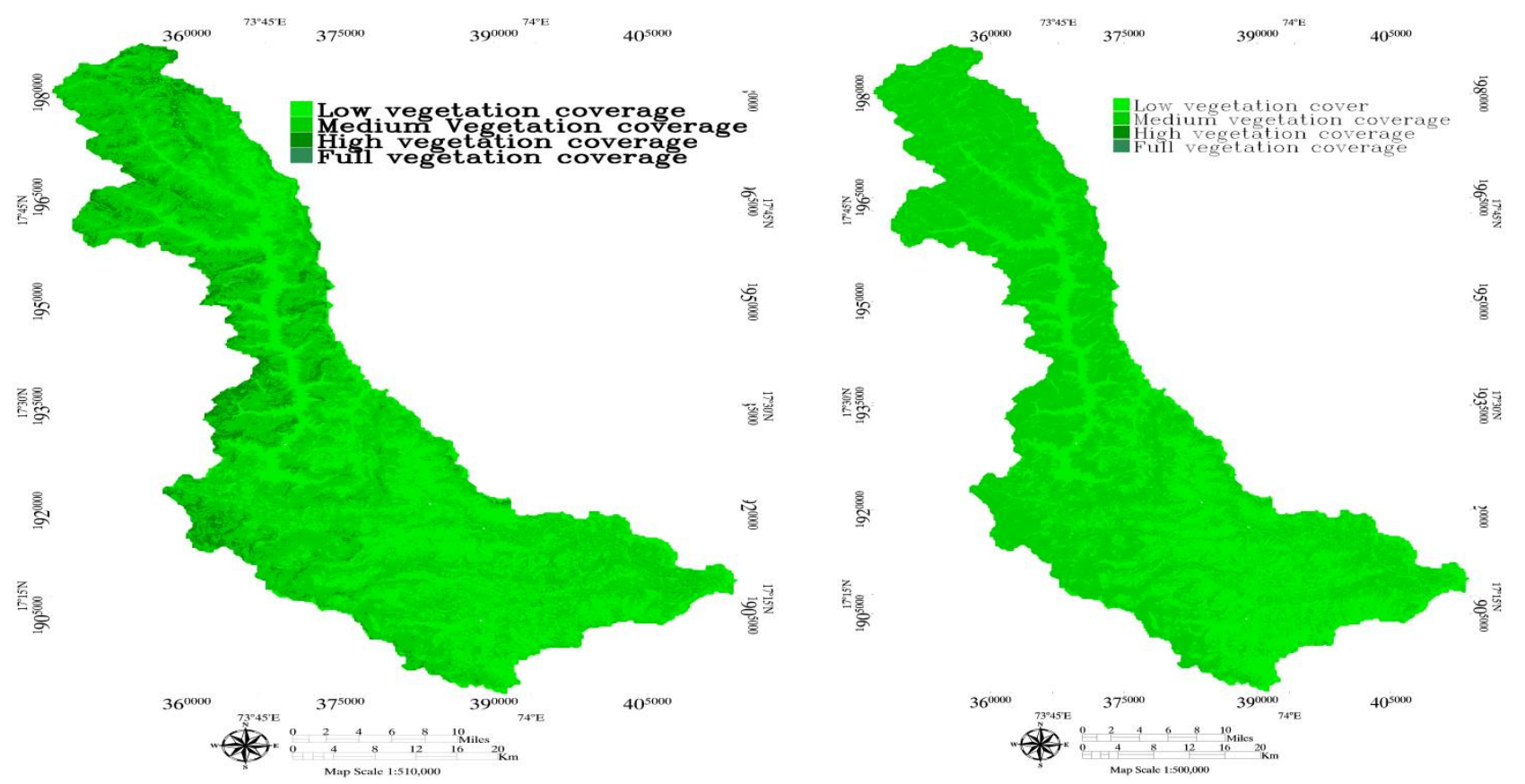

Fig.4a Vegetation coverage grade during 1999

Fig.4b Vegetation coverage grade during 2015 
Table.1 Details of land use pattern (all figures in $\mathrm{Km}^{2}$ )

\begin{tabular}{|c|c|c|c|c|c|c|c|c|}
\hline Year & $\begin{array}{c}\text { Agricultural } \\
\text { land }\end{array}$ & $\begin{array}{c}\text { Hilly } \\
\text { land }\end{array}$ & $\begin{array}{c}\text { Deep } \\
\text { water } \\
\text { body }\end{array}$ & $\begin{array}{c}\text { shallow } \\
\text { water } \\
\text { body }\end{array}$ & $\begin{array}{c}\text { Forest } \\
\text { land }\end{array}$ & $\begin{array}{c}\text { Rocky / } \\
\text { Hard } \\
\text { surface }\end{array}$ & $\begin{array}{c}\text { Scrub/ } \\
\text { Open } \\
\text { forest land }\end{array}$ & Total \\
\hline 1999 & 770.96 & 713.6 & 86.59 & 26 & 259 & 58.79 & 0 & 1915 \\
\hline 2015 & 645 & 618 & 91.00 & 24.57 & 0 & 183.45 & 353 & 1915 \\
\hline
\end{tabular}

Table.2 Percentages areal distribution of LULC classes in the study area

\begin{tabular}{|c|c|c|c|c|c|c|c|c|}
\hline Year & $\begin{array}{c}\text { Agricultural } \\
\text { land }\end{array}$ & $\begin{array}{c}\text { Hilly } \\
\text { land }\end{array}$ & $\begin{array}{c}\text { Deep } \\
\text { water } \\
\text { body }\end{array}$ & $\begin{array}{c}\text { shallow } \\
\text { water } \\
\text { body }\end{array}$ & $\begin{array}{c}\text { Forest } \\
\text { land }\end{array}$ & $\begin{array}{c}\text { Rocky / } \\
\text { Hard } \\
\text { surface }\end{array}$ & $\begin{array}{c}\text { Scrub/ } \\
\text { Open } \\
\text { forest land }\end{array}$ & Total \\
\hline $\mathbf{1 9 9 9}$ & 40.25 & 37.26 & 4.52 & 1.35 & 13.52 & 3.06 & 0 & 100 \\
\hline $\mathbf{2 0 1 5}$ & 33.68 & 32.27 & 4.75 & 1.28 & 0 & 9.57 & 18.43 & 100 \\
\hline
\end{tabular}

Table.3 Net Change in areal extent $\left(\mathrm{km}^{2}\right)$ of LULC (values in parenthesis show changes in percentages)

\begin{tabular}{|c|c|c|c|c|c|c|c|}
\hline Year & $\begin{array}{l}\text { Agricultural } \\
\text { land }\end{array}$ & $\begin{array}{l}\text { Hilly } \\
\text { land }\end{array}$ & $\begin{array}{l}\text { Deep } \\
\text { water } \\
\text { body }\end{array}$ & $\begin{array}{c}\text { shallow } \\
\text { water } \\
\text { body }\end{array}$ & $\begin{array}{l}\text { Forest } \\
\text { land }\end{array}$ & $\begin{array}{c}\text { Rocky / } \\
\text { Hard } \\
\text { surface }\end{array}$ & $\begin{array}{c}\text { Scrub/ } \\
\text { Open } \\
\text { forest } \\
\text { land }\end{array}$ \\
\hline $\begin{array}{c}1999 \text { - } \\
2015\end{array}$ & $\begin{array}{l}-125.96 \\
(-16.33)\end{array}$ & $\begin{array}{c}-95.6 \\
(-13.39)\end{array}$ & $\begin{array}{c}4.52 \\
(5.22)\end{array}$ & $\begin{array}{l}-1.43 \\
(-5.5)\end{array}$ & $\begin{array}{l}-259 \\
(-100)\end{array}$ & $\begin{array}{c}124.66 \\
(212.04)\end{array}$ & $\infty^{353}$ \\
\hline
\end{tabular}

Table.4 Accuracy assessment for the year Nov. 1999

\begin{tabular}{|c|c|c|c|c|c|c|c|c|}
\hline LULC & $\begin{array}{c}\text { Agricul } \\
\text { tural } \\
\text { land }\end{array}$ & $\begin{array}{l}\text { Hilly } \\
\text { land }\end{array}$ & $\begin{array}{l}\text { Deep } \\
\text { water } \\
\text { body }\end{array}$ & $\begin{array}{c}\text { Shallow } \\
\text { water } \\
\text { body }\end{array}$ & $\begin{array}{l}\text { Fores } \\
t \text { land }\end{array}$ & $\begin{array}{c}\text { Rocks / } \\
\text { Hard } \\
\text { surface }\end{array}$ & $\begin{array}{c}\text { Tota } \\
1\end{array}$ & $\begin{array}{l}\text { Producer } \\
\text { s } \\
\text { Accuracy } \\
(\%)\end{array}$ \\
\hline Agricultural land & 117 & 0 & 0 & 0 & 0 & 0 & 117 & 100 \\
\hline Hilly land & 0 & 272 & 0 & 0 & 0 & 0 & 272 & 100 \\
\hline Deep water body & 0 & 0 & 216 & 0 & 0 & 0 & 216 & 100 \\
\hline Shallow water body & 0 & 0 & 0 & 21 & 0 & 6 & 27 & 77.78 \\
\hline Forest land & 0 & 0 & 0 & 0 & 105 & 0 & 105 & 100 \\
\hline Rocks / Hard surface & 0 & 0 & 0 & 13 & 0 & 171 & 184 & 92.93 \\
\hline Total & 117 & 272 & 216 & 34 & 105 & 177 & 921 & \\
\hline $\begin{array}{l}\text { Consumers Accuracy } \\
(\%)\end{array}$ & 100 & 100 & 100 & 61.76 & 100 & 96.61 & & \\
\hline
\end{tabular}


Table.5 Accuracy assessment for the year Nov. 2015

\begin{tabular}{|c|c|c|c|c|c|c|c|c|}
\hline LULC & $\begin{array}{l}\text { Agricultural } \\
\text { land }\end{array}$ & $\begin{array}{l}\text { Hilly } \\
\text { land }\end{array}$ & $\begin{array}{l}\text { Deep } \\
\text { water } \\
\text { body }\end{array}$ & $\begin{array}{c}\text { Shallow } \\
\text { water } \\
\text { body }\end{array}$ & $\begin{array}{c}\text { Scrub/ } \\
\text { Open } \\
\text { forest } \\
\text { land }\end{array}$ & $\begin{array}{l}\text { Rocks } \\
\text { / Hard } \\
\text { surface }\end{array}$ & Total & $\begin{array}{c}\text { Producers } \\
\text { Accuracy } \\
(\%)\end{array}$ \\
\hline Agricultural land & 306 & 1 & 0 & 0 & 0 & 0 & 307 & 99.67 \\
\hline Hilly land & 0 & 91 & 0 & 0 & 0 & 0 & 91 & 100 \\
\hline Deep water body & 0 & 0 & 224 & 0 & 0 & 0 & 224 & 100 \\
\hline $\begin{array}{l}\text { Shallow water } \\
\text { body }\end{array}$ & 0 & 0 & 0 & 17 & 0 & 6 & 23 & 73.91 \\
\hline $\begin{array}{l}\text { Scrub/ Open } \\
\text { forest land }\end{array}$ & 0 & 0 & 0 & 0 & 51 & 0 & 51 & 100 \\
\hline $\begin{array}{l}\text { Rocks / Hard } \\
\text { surface }\end{array}$ & 0 & 0 & 0 & 0 & 0 & 21 & 21 & 100 \\
\hline Total & 306 & 92 & 224 & 17 & 51 & 27 & 921 & \\
\hline $\begin{array}{l}\text { Consumers } \\
\text { Accuracy (\%) } \\
\end{array}$ & 100 & 98.91 & 100 & 100 & 100 & 77.78 & & \\
\hline
\end{tabular}

Table.6 Areal distribution of different vegetation grades during 1999-2015 $\left(\mathrm{Km}^{2}\right)$

\begin{tabular}{|c|c|c|c|c|c|}
\hline Year & LVC & MVC & HVC & FVC & Total \\
\hline 1999 & 699.9 & 1080 & 135.1 & 0 & 1915 \\
\hline 2015 & 782.5 & 1132 & 0.45 & 0 & 1915 \\
\hline
\end{tabular}

As shown in Table 6, there is a negative change of vegetation coverage or health for the river basin during 1999-2015, as most of high vegetation coverage (HVC) has disappeared with a great increase of low (LVC) and medium vegetation coverage (MVC).

As shown in Figure $4 \mathrm{a}$ and $4 \mathrm{~b}$, there is significant difference in NDVI during the year 1999 to 2015. In details, dense forest land has the highest value of NDVI, followed by open forest land, agricultural land, dry land, waste grassland, construction land, and bare land with glacier or snow-capped land and water body for the lowest value.

Hence, this study reveals the shifting of high vegetation grade forest cover into non- productive low vegetation grade waste land and water body.

Remote sensing and GIS act as a powerful tool for obtaining reliable temporal and spatial information (Selcuk, 2008). Assessing and monitoring LULC changes are helpful for biodiversity conservation, planning afforestation and land cover management (Felicia, 2017). The present study showed how the Remote Sensing and GIS technology can be useful for land use/land cover classification. The results show that due to natural and anthropogenic activities forest has been degraded and agricultural land has been reduced showing hazardous alarm for ecosystem of the basin. Due to ignorance of soil protection work the top soil layer has been removed and converted into rocks/hard surface over significant area, it also indicates 
the need of implementing soil conservation measures. The conversion of dense forest into open forest can disturb the ecosystem of the basin. Information on land use/land cover and possibilities for their optimal use is essential for the selection, planning and implementation of land use schemes to meet the increasing demands for basic human needs and welfare.

\section{Acknowledgements}

The authors wish to thank the Inspire programme, Department of Science and Technology, Government of India for providing financial support to complete this research.

\section{References}

Ashraf, M. D., and Yasushi, Y., 2009. Using remote sensing and GIS to detect and monitor land use and land cover change in Dhaka Metropolitan of Bangladesh during 1960-2005. Environmental Monitoring Assessment. 150:237-249.

Dewi, K., 2009. Forest Cover Change and Vulnerability of Gunung Merbabu National Park. M.Sc. Thesis, International Institution for GeoInformation Science and Earth observation, Enschede.

Felicia, O. A., 2017. Land change in the central albertine rift: Insights from analysis and mapping of land use land cover change in North-Western Rwanda. Applied Geography. 87: 127138.

Guangming, Y., Qun, Z., Shan, Y., Limei, H., Xiaowei, L., Yi, C., and Yuge, Z., 2010. On the intensity and type transition of land use at the basin scale using RS/GIS: a case study of the Hanjiang River Basin. Environmental Monitoring Assessment.160:169-179.
Jian, P., Yinghui, L., Hong, S., Yinan, H., and Yajing P., 2012. Vegetation coverage change and associated driving forces in mountain areas of Northwestern Yunnan, China using RS and GIS. Environmental Monitoring Assessment.184:4787-4798.

Jie, Y., Zhane, Y., Haidong, Z., Shiyuan, X., Xiaomeng, H., Jun, W., and Jianping, W., 2011. Monitoring urban expansion and land use/land cover changes of Shanghai metropolitan area during the transitional economy (1979-2009) in China. Environmental Monitoring Assessment. 177:609-62.

Kidane, W., and Bogale, G., 2017. Eff ect of land use land cover dynamics on hydrological response of watershed: Case study of Tekeze Dam watershed, northern Ethiopia. International Soil and Water Conservation Research.5: 116.

Md, A. H., Abdus, S., Mohammad, S. H. C., Mst, N. N., Md, S. I. S., Nuruddin., Md, J., and Masao, K., 2008. Evaluation of land-use pattern change in West Bhanugach Reserved Forest, Bangladesh, using remote sensing and GIS techniques. Journal of Forestry Research.19 (3):193-198.

Nair, C.T.S., and Tieguhong, J., 2004. African Forests and Forestry: An Overview. A report prepared for the Project Lessons learnt on Sustainable Forest Management in Africa. FAO, Rome.

Niem, N. H., Hone, J. C., Yu, P. L., and Dung, P. D., 2010. Effects of land cover changes induced by large physical disturbances on hydrological responses in central Taiwan. Environmental Monitoring Assessment.166: 503-520.

Sandeep, S., Garg, P.K., Ashutosh, S., and Abhishek, K. M., 2015. Assessment of land use land cover change in Chakrar watershed using geospatial technique. 
Tropical Plant Research. 2(2): 101107.

Selcuk, R., 2008. Analyzing land use land cover changes using remote sensing and GIS in Rize, North-East Turkey. Sensors. 8: 6188-6202.

Sumedha, M., Madhushree, M., Gracy, O., Pawan, K. J., 2010. Landscape approach for quantifying land use land cover change (1972-2006) and habitat diversity in a mining area in Central
India (Bokaro, Jharkhand). Environmental Monitoring Assessment. 170:215-229.

Zahra, H., Rabia, S., Sheikh, S. A., Amir, H. M., Neelam, A., Amna, B., and Summra, E., 2016. Dynamics of land use and land cover change (LULCC) using geospatial techniques: a case study of Islamabad Pakistan. Springer Plus. 5: 812.

\section{How to cite this article:}

Tarate Suryakant Bajirao, Pravendra Kumar and Anil Kumar. 2018. Spatio-Temporal Variability of Land use/Land Cover within Koyna River Basin. Int.J.Curr.Microbiol.App.Sci. 7(09): 944-953. doi: https://doi.org/10.20546/ijcmas.2018.709.114 